\title{
An exploration of the idea of ecodomy in Calvin's view of God and the world: Its implications for churches in South Africa today
}

\begin{tabular}{|c|c|}
\hline \multicolumn{2}{|l|}{$\begin{array}{l}\text { Author: } \\
\text { Jerry Pillay }{ }^{1}\end{array}$} \\
\hline \multicolumn{2}{|c|}{$\begin{array}{l}\text { History and Church Polity, } \\
\text { University of Pretoria, } \\
\text { South Africa }\end{array}$} \\
\hline \multicolumn{2}{|c|}{$\begin{array}{l}\text { Correspondence to: } \\
\text { Jerry Pillay }\end{array}$} \\
\hline \multicolumn{2}{|c|}{$\begin{array}{l}\text { Email: } \\
\text { jerry.pillay@up.ac.za }\end{array}$} \\
\hline \multicolumn{2}{|c|}{$\begin{array}{l}\text { Postal address: } \\
12 \text { Kwartz Street, Farrarmere } \\
1501 \text {, South Africa }\end{array}$} \\
\hline \multicolumn{2}{|c|}{$\begin{array}{l}\text { Dates: } \\
\text { Received: } 14 \text { May } 2015 \\
\text { Accepted: } 11 \text { Aug. } 2015 \\
\text { Published: } 27 \text { Oct. } 2015\end{array}$} \\
\hline \multicolumn{2}{|c|}{$\begin{array}{l}\text { How to cite this article: } \\
\text { Pillay, J., 2015, 'An } \\
\text { exploration of the idea of } \\
\text { ecodomy in Calvin's view } \\
\text { of God and the world: Its } \\
\text { implications for churches in } \\
\text { South Africa today', Verbum } \\
\text { et Ecclesia 36(3), Art. \#1474, } \\
10 \text { pages. http://dx.doi. } \\
\text { org/10.4102/ve.v36i3.1474 }\end{array}$} \\
\hline \multicolumn{2}{|c|}{$\begin{array}{l}\text { Note: } \\
\text { This article represents a } \\
\text { theological reflection on the } \\
\text { Faculty Research Theme (FRT) } \\
\text { of the Faculty of Theology, } \\
\text { University of Pretoria, entitled } \\
\text { 'Ecodomy - Life in its fullness'. } \\
\text { The theme is portrayed from } \\
\text { the perspective of various } \\
\text { theological disciplines. A } \\
\text { conference on this theme was } \\
\text { held on } 27-28 \text { October } 2014 \text {. }\end{array}$} \\
\hline \multicolumn{2}{|c|}{$\begin{array}{l}\text { Copyright: } \\
\text { (C) 2015. The Authors. } \\
\text { Licensee: AOSIS } \\
\text { OpenJournals. This work is } \\
\text { licensed under the Creative } \\
\text { Commons Attribution } \\
\text { License. }\end{array}$} \\
\hline \multirow[b]{2}{*}{ 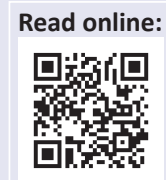 } & \\
\hline & $\begin{array}{l}\text { Scan this QR } \\
\text { code with your } \\
\text { smart phone or } \\
\text { mobile device } \\
\text { to read online. }\end{array}$ \\
\hline
\end{tabular}

The Faculty of Theology chose as its theme oikodome, which speaks about the fullness of life for all. This article explored this theme by looking at John Calvin's understanding of God and the world. In this article, working from the premise of the sovereignty of God, the author attempted to show that undergirding Calvin's theology is the idea of oikodome. The author showed that for Calvin everything in life is connected to God and thus the idea of oikodome is deeply rooted in Calvin's theology. The author illustrated this by examining significant themes in Calvin's teachings on the Trinitarian God, creation, humanity and providence, state and church, transformation of society, concern for the poor, and education. The author used this information to show what implications the idea of oikodome has for churches in South Africa today, especially in the context of poverty and struggle. The author calls on churches to embrace the theological foundation explicated by Calvin in their endeavour to work toward the fullness of life for all people.

\section{Introduction}

Under the influence of some of the 19th century German historians of dogma it was long popular to seek for one controlling idea in Calvin's theology. ${ }^{1}$ Usually it was said to be predestination or the sovereignty of God, whereas the controlling principle of Martin Luther was said to be the concept of justification by faith (Hall 2010:189). Predestination is no longer said to be the centre of Calvinism. For example, Francois Wendal, in 1950, with careful scholarship, showed that predestination was not the controlling factor in Calvin's theology (Wendal 1963:263-284). In this article, working from the premise of the sovereignty of God, the author will attempt to show that undergirding Calvin's theology is the idea of ecodomy.

Whilst the 'sovereignty of God' is not the only theme in Calvin's theology it is difficult not to talk about it. For Calvin the sovereignty of God is not only the foundation and focal point for the doctrine of redemption; it is also the very essence and reason for all human activity. As will be shown, for Calvin this meant that the human person was responsible to God in all areas of their life. It is not within the scope of this article to present a detailed account of theological discussions on the themes explored; the aim is to show how the idea of ecodomy serves as a connecting thread in Calvin's view of God and the world and to briefly examine its implications for churches in South Africa today. For this reason, the author will selectively engage some themes from Calvin's teachings in order to illustrate the point.

However, before the author proceeds to show how Calvin's theology is influenced by the idea of ecodomy, it is necessary to first define what is meant by the use of this word. The Greek word oikodome means to build. In the Septuagint it means edification, building, house. In essence, oikodome refers to life in its fullness. ${ }^{2}$ The Greek word oikoumene (ecumenism) refers to the whole inhabited earth. It is thus not surprising that since its inception the World Council of Churches understood its own focus as 'everything that relates to the whole task of the whole church to bring the gospel to the whole world'. The ecumenical movement sees the world in a particular light - of what it is, could be, should be, and will become. In recent years, theologians intentionally relate the oikoumene of the church to the oikounomia or fullness of the life of the Trinitarian God, to be reflected in the life of the church. The oikoumene is furthermore related to the global political and economic realities, critically

\footnotetext{
1.For example, Eberhard Busch locates the identity of Reformed theology in its theocentric orientation, its attempt to reform society according to the divine commandments and its anti-hierarchical ecclesiological concept; Colin Gunton focuses on its doctrine of predestination; Daniel Migliore sketches a Trinitarian ecclesiology as essentially Reformed, whereas Mark Achtemeier concentrates on the notion of the unio cum Christo; Douglas Farrow considers the Reformed conceptions of the Ascension and of the Lord's Supper to the notion of the unio cum Christo; Douglas Farrow considers the Reformed conceptions of the Ascension and of the Lord's Supper to
be crucial; George Hunsinger holds the combination of its orthodox doctrine and progressive social ethics to be unique and Bram van de Beek its anti-ideological attitude. See Van den Brink (2010:410).

2.For a deeper exploration of the word see Jacobus Kok (2014).
} 
discussed from the perspective of the political economy of the Holy Spirit, as well as to the habitable earth and, in fact, the whole of creation and ecology. The oikos of church, political economy and earth all together form part of the one household of life in the economy of the living Triune God. Ecodomy thus refers to the fullness of life for all (John 10:10). It establishes that the earth belongs to the Lord and everything in it (Psalm 24:1). This calls for the integration and harmonious living of all creation, both living and non-living, under the sovereign rule of God. It also speaks of the responsibility of human beings to care, nurture and build God's household (world) with the ideals and values of God's reign.

This is precisely how Calvin viewed God and the world. The central theme of Calvinist theology, as will be shown, is the conviction that every human being has to do with the living God every moment of every day. For Calvin, everything in life is connected to God and therein lies the fullness of life. It is thus no small wonder as to why he wanted to establish the reign and presence of God in every aspect of life in Geneva. In the next section, the author will illustrate how Calvin's theology was deeply influenced by the idea of oikodome.

\section{The Trinitarian God}

The idea of oikodome is deeply ingrained in Calvin's understanding of God. He developed his doctrine of the Trinity against the background of the dogma of the early church, though not without criticism. Calvin's intention was to show that God is one, and yet Father, Son, and Holy Spirit. In indicating general proof for the Trinity he refers to Genesis 1:26 where he deduces from the plural in this text ('Let us make man') that the one Being of God must contain more than one Person. In the New Testament Calvin continually combines two passages that reveal a (proto-) Trinitarian or triadic structure. One is the baptismal formula of Matthew 28:19, which is connected with Ephesians 4:5, where one baptism, one faith, and one God are juxtaposed. According to the reformer, the combination of these texts shows convincingly that God is one (Selderhuis 2009:248).

Calvin is generally quite restrained when he speaks about God's Being. Perhaps this is primarily because he was of the opinion that we cannot fathom the Being of God, which is characterised as spiritual (spiritualis), infinite (immensus), and incomprehensible (incomprehensibilis). However, it is interesting to note that most of the adjectives he uses often express either the exalted nature or the unity of the Being of God. Calvin underscores the unity of God's Being in several ways. In this regard he uses words such as unity (unitas), being 'undivided', and simplicity (simplicitas). With these words Calvin wants to indicate that within the Being of God there can be no question of any kind of separation or division. He establishes that each of the Persons share the indivisible Being of God in like measure. ${ }^{3}$ In that way the Father, the

3.Calvin's definition of the Trinitarian concept of Person is known from the 1559 edition of the Institutes: "By "Person", then, I mean ... a subsistence in the Divine Being - a subsistence which, while related to the other two, is distinguished from them by incommunicable properties' (Inst. I.13.6).
Son, and the Holy Spirit are God in the full sense of the Word. Calvin sees in the word Person not only a substantial aspect ('subsistence'), but also a relational aspect ('mutually related'). Thus, for Calvin, the three Persons are mutually and economically connected to each other in various ways. Calvin uses the simplified variant to describe this: the Father as Source, the Son as Wisdom, and the Holy Spirit as Power. In this he associates the immanent and economic Trinitarian relationship. ${ }^{4}$ Within the Trinity the Father is the source of the Godhead, but also the source from which all blessings and good flows. The Son is Wisdom living eternally with God, and at the same time he governs God's works in all wisdom and he grants wisdom to sinful people. The Spirit is the essential Power who proceeds from the Father and the Son and who completes the works of God powerfully and effectively. Calvin attempts to show that the works of Father, Son and Holy Spirit are connected to each other quite harmoniously.

In this we see the unity in diversity in the Godhead. God is one in Being, and yet also Father, Son and Holy Spirit with distinctive properties and mutual relationships interchangeably. In this Trinitarian relationship we see the concept of community firmly established in the very nature and work of God. God is community. God is thus interested in building community, one human community. Hence, the idea of ecodomy is embedded in the very nature of God depicting harmony, unity and community.

In South Africa under apartheid the human community was separated and destroyed by racial and economic oppression. The task of the church is to rebuild this human community. Some 20 years after the establishment of a democratic South Africa it is questionable whether we are succeeding in the endeavour of building such a community. Churches in South Africa have not done and are not doing enough in the area of reconciliation and healing of the nation, an important task in building human community. It is thus not surprising that racial and ethnic tension is becoming more deeply entrenched and this is also finding its way into xenophobic tendencies and violence. The church needs to assume its role in building the human community in South Africa because at the heart of the Trinitarian understanding of God is the idea of community. Embedded in the sovereignty of God, the idea of 'fullness of life in Jesus Christ' was to influence much of Calvin's theological thinking and view about the world and humankind. Indeed, it was to make significant contributions to political, societal, economic and cultural change in the world.

\section{Creation, humanity and providence}

Calvin's idea of oikodome can be seen in his views on creation and providence. His discussion of the created order encompasses all aspects of nature, ranging from the angelic creation to the role of government. He saw the unity and

4.A number of studies emphasise that in Calvin's concept considerably more attention is paid to the economic than the immanent Trinity (see e.g. Butin 1995, also see Letham 2004). 
continuity of God's presence in the world. According to Calvin, the centre of Christian theology is the knowledge of God and of humanity. They both have a certain connection. In Christ, Calvin sees God and humanity bound together indissolubly, though such connectedness of the two does not mean the negating of their difference. God is the Maker of heaven and earth. This is an affirmation of divine sovereignty, universal providence, creaturely dependence and human responsibility. Nothing in creation is independent of God; nothing is equated with God. God is the sole source and providential benefactor of all being. God is the ultimate and universal proprietor: 'The earth is the Lord's and all that is in it, the world, and all those who live in it' (Ps 24:1, NRSV). Thus, God values biophysical reality and the needs of every form of life, human and otherwise. The planet was created as a habitat to be shared by all. God's compassionate concern covers the whole. God is not only beyond but in the creation as the vivifying, reconciling, liberating, and sanctifying presence of the Spirit. Indeed, God is intimate with the creation, experiencing thejoys and agonies of all creatures (Rom 8:19-25). The whole creation is thereby endowed with value and dignity by association with the sacred. It is to be valued as it is valued by God, who chose to be present within it.

Hence, Calvin took issue with his medieval predecessors who advocated that God moved the first sphere (the firmament) and the remaining spheres were set in motion as through a chain whereby motion was transmitted from the higher to the lower spheres, extending all the way to the earth. Consequently, this posited a certain remoteness of God and God's providence. In Calvin's view, the idea of motion inherent in the Aristotelian cosmos as well as the atomism of Epicurus contradicted the Christian doctrines of creation and providence, both of which required the activity, care, and nearness of God to his creation. Whilst Calvin never denied the existence of causae secundae, he warned that they must never obscure the sovereignty and presence of God at work in these media (Inst. I.16.2; CO 8, 348; 31, 177, 331, 464; $32,430-431,550-552)$. He thus accepted Genesis 1:1 and John $1: 3$ as proof that the world was created ex nihilo through the Word (OE XI/1, 16) and 'not emanated coincidentally from particles' (CO 32, 435). Commenting on Psalm 104:5, Calvin affirms his point:

The stability of the earth proclaims the glory of God, for how does it hold its place unmoved, when it is suspended in the midst of the air, and is supported only by water... Nothing, in the world is stable except as it is upheld by the hand of God. (CO $32,86-87$; Inst. I.5,6)

For Calvin, everything is connected to God. God's sovereignty pervades heaven and earth and God holds all things together.

This theological point of departure has become the basis for many partnerships both nationally and internationally addressing globalisation, poverty and ecological issues. ${ }^{5}$ For example, the Conference on Poverty, Wealth and Ecology

5.For examples of the environmental work of churches in Latin America, Europe, the Czech Republic, Belgium and Africa see Pavlovic (2011:128-130). in Europe makes this clear as a motivation for (regional) integration of Europe:

The primary motivation behind the Churches' involvement is the theological understanding of engagement within God's creation, with consequences and benefits for the people in Europe and the participation of European peoples in shaping a united continent. Therefore an aim of the Churches' engagement with European integration is to accompany it with a theologically based ethical and anthropological perspective, which can provide criteria for the evaluation of the European policies aimed at fostering integration. ${ }^{6}$

The idea of a united creation, with all its diversities, is also deeply entrenched in the Budapest Call for Climate Justice:

We have criticized the primacy of economy over people and creation as a whole. We recognise the relational character of life in the 'community of creation' and the special God-given responsibility of human beings in this community. We recognize the fundamental interdependence between human societies and the rest of creation, and their ultimate dependence on God the Creator, the Redeemer and the Sustainer. Therefore, we as the people of God are called to participate in the work of God in this world, extending God's love and care to all human and nonhuman members of the 'community of creation'. '

The idea of community is strongly supported in the African concept of ubuntu (humaneness) in which life in relationship is underscored: 'I am because we are, and we are because I $\mathrm{am}^{\prime}$. The individual's identity is inseparable from identity within the wider community, which includes past, present and future generations, as well as flora and fauna, the physical environment and the spiritual realm (Mshana 2012:12). In the African context the connection with the earth is significant. It is thus essential that the church addresses the problem of land ownership and land use in South Africa. The church is called upon to exercise responsible leadership as it speaks about 'life in abundance' by drawing the connection between justice and stewardship for Creation. In spite of its diversity, everything is connected and accountable to God. This is precisely what Calvin attempted to indicate in his view about creation and providence: unity in diversity and fullness of life. For Calvin, all creation is connected to one another and ultimately all to the Sovereign God. This speaks of responsibility and accountability to each other and to God.

\section{State and church}

The idea of oikodome can be clearly illustrated in Calvin's understanding of the relationship between state and church. Admittedly, the reformer saw a clear distinction between the role of the church and that of the state: 'There is a twofold government in man [sic]: one aspect is spiritual ... the second is political ... two worlds, over which different kings and different laws have authority' (III.XIX,15;847). The state for Calvin is essentially an organ of constraint in which the dynamic element is represented by the magistrate, while the

6.'European integration - A way forward?' Church and Society Commission of the Conference for European Churches, 2009.

7.Declared in the WCC-CEC Consultation on Poverty, Wealth and Ecology, Budapest, 12 November 2010. 
static element appears in the laws. The state is to secure the minimum of peace and concord required by human society for its existence. However, the state has not only to maintain peace; it must also endeavour to maintain, here below, a certain standard of morality or, as Calvin calls it, 'some taste of the celestial realm' (Gamble 1992:114). Calvin first distinguishes and then joins spiritual and civil government and sets his discussion of civil government in the context of his teaching on providence, Christian freedom, and the church (IV.XX.1-2). The task of government, according to Calvin, is to 'provide a public manifestation of religion that may exist among Christians, and that humanity be maintained among people'. This is to imply that the duty of magistrates 'extends to both tables of the law' $(9 ; 1495)$, that is, to man's [sic] duty to God, as well as to his duties to other people. Thus, God 'entrusts the condition of the church to their protection and care' (5;1491). Simply put, the church's mission is to bear testimony among the people to Christ and the Christian faith; the state's highest function is to bring about respect for this mission. Although there is a differentiation in role between church and state, Calvin saw a unity in purpose in so far as both church and state are subject to the authority of God. There is cooperation between the spiritual and the civil powers to ensure that the people live according to God's Word. He envisaged human society as a whole, directed simultaneously by church and state, and not by one of these institutions to the detriment of the other.

No doubt, Calvin's ideas and actions were to influence modern civil governance. It is not surprising that Harvard historian George Bancroft asserted that Calvin's ideas buttressed liberty's cause (Schaff 1979:8, 264). He and others noted the influence of his thought on the development of various freedoms in western Europe and America. In the middle of the 19th century already Bancroft extolled Calvin as 'the foremost of modern republican legislators', who was responsible for elevating the culture of Geneva into 'the impregnable fortress of popular liberty, the fertile seed-plot of democracy' (Bancroft 1855:8, 522). Bancroft even credited the 'free institutions of America as derived chiefly from Calvinism through the medium of Puritanism'. Recently, John Witte Jr (2010) noted how Calvin's teachings on authority and liberty, duties and rights, and church and state had influenced many Protestant lands. He states that as a result of its adaptability this 'rendered early modern Calvinism one of the driving engines of Western constitutionalism'. According to John Witte Jr (2007):

a number of our bedrock Western understandings of civil and political rights, social and confessional pluralism, federalism and social contract, and more owe a great deal to Calvinist theological and political reforms. (p. 2)

Unfortunately, Calvin's teachings were not always used in a positive way. For example, in South Africa it was used to justify apartheid, a policy which enforced separation by racial discrimination and skin pigmentation. However, this was not done by Calvin's view of state and church but by a total misrepresentation of his teaching on election and predestination. White (Afrikaner) South Africans, believing that they were the chosen people of God, considered themselves as a superior race and thus protected their rights and privileges by state legislation, which led to laws which oppressed the majority black population in the country. This was not an expression of Calvin's understanding of unity in diversity but a propagation of divisive oppression. Flip Buys in his article on Calvin and racism establishes that:

The basic doctrines of the sovereignty of God as it has been understood and taught in the Calvinistic tradition crushes thoughts and practices of racial and tribal discrimination. The transforming grace of God as it is taught in true Calvinism is also the best facilitator of holistic racial reconciliation, healing and community development. ${ }^{8}$

The task of the church in South Africa, whilst maintaining its distinctive identity and role as suggested by Calvin above, is to partner and participate with the state in (re)building a broken and divided nation. The struggle for the fullness of life for all people and the unity of humankind should occupy the agenda and mission of the church.

In the next section, some of the ways in which this can be done will be outlined.

\section{Transformation of society}

With his high view of the sovereignty of God, Calvin proceeded to transform society. Calvin's theology was one which took the believer's responsibility in the world more seriously than Luther. For Calvin, the Christ who was exalted to God's right hand was pre-eminently the active Christ. In a sense, Calvin subscribed to an eschatology in the process of being fulfilled. He used the term regnum Christi (the reign of Christ) in this respect, viewing the church as an intermediary between the exalted Christ and the secular order. ${ }^{9}$ Such a theological point of departure could not but give rise to the idea of mission as 'extending the reign of Christ', both by the inward spiritual renewal of individuals and by transforming the face of the earth through filling it with 'the knowledge of the Lord'. This particular view led Calvin to bring about social transformation in Geneva (McKim 1984:175). He believed that the best possible way to transform society was to make it a truly Christian community. ${ }^{10}$ It is interesting to note how he linked his religious views with the transformation of society. Calvin believed that his own time was caught up in a spiritual and moral crisis whose resolution required his own ardent efforts. To set the world right was what he was most insistently 'called' to do; 'God sends prophets and teachers',

8.See http://wrfnet.org/resources/2009/01/Calvinism-and-racism-south-africanperspective.

9.Why did Calvin draw a distinction between sacred and secular history in the first place? According to Richardson (cited in Hall 2010:218), Calvin had no other choice. He was a child of his times and it never occurred to him to think otherwise. Also see Hall (2010) for the distinction between sacred and secular, as Calvin might have understood it.

10.Cheneviere (as cited in Gamble 1992:108) points out that many Protestants understand theocracy to be a political regime dominated by clergy. He considers this erroneous. A theocracy simply designates a society in which authority is regarded as emanating from God and exercised by his representatives, which denotes not the clergy exclusively, but any person endowed with power proceeding from God. 
he proclaimed, 'to bring the world to order' (Bouwsma 1988:191). This is what he attempted to do in Geneva.

Calvin's programme for dealing with the problems of his own age was based on his conception of God as 'legislateur et roy' of the universe. It was crucial for him 'that God governs us' (Bouwsma 1988:192). 'When our Lord Jesus Christ appeared', Calvin declared:

He acquired possession of the whole world; and his kingdom was extended from one end of it to another, especially with the proclamation of the Gospel ... God has consecrated the entire earth through the precious blood of his Son to the end that we may inhabit it and live under his reign. (Sermon No. 45 on Deuteronomy, 426-427)

This meant that religious reform also pointed to the reform of the secular realm. Calvin added that believers 'truly worship God by the righteousness they maintain within their society'. For those acquainted only with the characteristic theological face of Calvin, it must be noted that Calvin's theological thinking, like all great classic theologians, was deeply involved with the structures and realities of everyday life. W.F. Graham (1971) observes that:

For Calvin the world was to be taken seriously, and for him the real world involved shoemakers, printers, and clockmakers, as well as farmers, scholars, knights, and clergymen. Calvin's world-affirming theology is quite apparent. (p. 91)

It must be made clear, however, that even though Calvin argued for Christian involvement in the world he maintained a clear position about the world to come. Christians are called to meditate on the world to come while living in the tensions of this world. Calvin urges us to adopt the fundamental attitude of contemptio mundi (McKim 1984). He said:

Whatever kind of tribulation presses upon us, we must ever look to this end: to accustom ourselves to contempt for the present life and to be aroused thereby to meditate upon the future life. (p. 305)

The present life is full of vanities and allurements:

Stunned by the empty dazzlement of riches, power, and honors, [our minds] become so deadened that they see no farther. The heart also, occupied with avarice, ambition, and lust, is so weighed down that it cannot rise up higher. (McKim 1984:305)

Yet God calls us 'not to be captivated by such pandering' but to come away from a 'perverse love of this life' to a 'desire for a better one' (McKim 1984:306). This is the eternal life which God sets before us; he rescues us from 'this boundless abyss of all evils and miseries' and leads us into 'that blessed inheritance of his life and glory'. Thus, the Christian life 'strains towards a completion and fulfillment that belong to it only beyond death'. ${ }^{11}$

Calvin speaks in the strongest possible terms about total renunciation of this world: 'Indeed, there is no middle ground between these two: either the world must become worthless

11.Calvin's reasons for advocating contempt for the present life are not rooted primarily in a body-soul dichotomy, but are to be found in a contrast between the present life under the cross and the future life of the heavenly kingdom. to us or hold us bound by intemperate love of it' (3.9.2). He adds, 'if the earthly life be compared with the heavenly, it is doubtless to be at once despised and trampled underfoot' (3.9.4). Yet Calvin goes on to qualify this by explaining that the earthly life 'is never to be hated except in so far as it holds us subject to sin; although not even hatred of that condition may ever properly be turned against life itself' (3.9.4). For 'this life, however crammed with infinite miseries it may be, is still rightly to be counted among those blessings of God which are not to be spurned' (3.9.3).

What Calvin is advocating here is that Christians be fully involved in the present world - they should accept God's good gifts with thankfulness and be active in all spheres of human endeavour - yet manifest an outlook oriented primarily toward the future:

We must remember to distinguish between the blessings of the present and those of the future. For in this world God blesses us in such a way as to give us a mere foretaste of His kindness, and by that taste to entice us to desire heavenly blessings with which we may be satisfied. That is why the blessings of this present life are not only mixed but almost destroyed here lest we should gain to luxuriate in it. (Torrance 1956:121)

In this sense the Christian stance which Calvin urges is a via media. Christians are to live midway between the 'brutish love of this world' (3.9.1) characteristic of the sinful self and the final perfection and blessedness which the saints will achieve in the 'kingdom of God' (3.9.6). What separates godly people from the worldly is 'their opposite attitudes to this present world and beyond'. With this view in mind Calvin attempted to transform the society of his day. It was an endeavour to create a better world in which everyone could live with justice, righteousness and peace. By and large, we know from Calvin's preaching that he tried to reform Geneva from the pulpit and through state policies. Whereas medieval society was largely one where common people were non-participants:

Calvinism taught previously passive people the styles and methods of political activity and enabled them successfully to claim the right of participation in that on-going system of political action that is the modern state. (Graham 1971:60)

Here again is evident a responsibility for society fostered by the Calvinist insistence that the will of God must extend to the total community. Striking in this is the idea of the fullness of life.

\section{Concern for the poor}

Calvin expressed a particular concern for the poor. He pointed out that the poor, in fact, serve a positive function in God's overall scheme of things. As his procureurs or receveur they serve as a type of barometer of the faith and charity of the Christian community:

God sends us the poor as his receivers. And although the alms are given to mortal creatures, yet God accepts and approves them and puts them to one's account, as if we had placed in his hands that which we give to the poor. ${ }^{12}$

12.Sermon 95 on Deuteronomy 15:11-15 (CO 27.338). This translation is found in Graham. Constructive Revolutionary, 69. 
For this reason he severely criticised 'the apparently liberal, who yet do not feel for the miseries of their brothers'. ${ }^{13}$ Calvin did not oppose wealth as such; he, however, was concerned that God's gifts be used for the relief of the whole community of God's people. Indeed, if there is any central theme in Calvin's social and economic thought, it is that wealth comes from God in order to be used to aid our brethren. The solidarity of the human community is such that it is inexcusable for some to have plenty and others to be in need. Calvin brought this message home in one of his sermons:

Let those, then, that have riches, whether they have been left by inheritance, or procured by industry and efforts, consider that their abundance was not intended to be laid out in intemperance or excess, but in relieving the necessities of the brethren. (Graham 1971:68)

Calvin considered poverty a serious problem. He believed that it was the Christian's responsibility to address this issue. Calvin and his pastors lived in conditions close to poverty, raising funds for the needy and lobbying the state to act for the poor. He employed the traditional organic metaphor for society (as found in Acts 2:42ft), in which, as he wrote, no member has 'power for itself nor applies it to its own private use, but each pours it out to the fellow members'; what chiefly matters is 'the common advantage of the whole body' (Graham 1971:68). Occasionally he identified this community with the whole human race. 'All people', he would maintain, 'are bound together as a sacred chain [which] ... should be embraced in one feeling of love' ${ }^{14}$

This particular view generally yielded, for him, to a more practical view of community-based on neighbourhood. 'All the blessings we enjoy', he proclaimed, 'have been entrusted to us by the Lord on this condition, that they should be dispensed for the good of our neighbors'. ${ }^{15}$ What we see here in Calvin's teachings is that we have moral responsibility as individuals, to act with personal integrity and show love towards one another. But we also have a collective responsibility for the society in which we live. We cannot act justly as individuals, if the structures within which we live are unjust. The vision of Christianity then is a corporate vision.

In Calvin's view money and goods ought to circulate in human society to the welfare of all. Humanity in solidarity one with another would participate in contributing according to one's vocation to the good of all. He maintained that the church teaches and acts to promote equality and restore human solidarity. It helps people to put their property to the use of all. Calvin saw the governing authorities as the agents of God for the welfare of the people. He thus condemned the rich and powerful who exploited their material advantage to increase the poverty of the poor. He favoured a system of loans to help the poor but maintained that the loans should be granted without interest. Calvin insisted on personal

13.Commentary on John 3:17 (CNTC 12.277).

14.Commentary Acts 13:36; Inst., II, viii, 55.

15.Inst., III, vii, 5. morality, righteousness and hard work. He vehemently attacked lazy people who did not contribute to a working society. His emphasis on hard labour led to a distorted view that linked hard labour with salvation and election. However, Calvin certainly did not intend this. He rather assumed hard work, but he wanted it clearly understood that hard labour did not give wealth. Only God provides wealth. No one will be advanced unless God advances him or her. Calvin's emphasis on hard labour was to be taken and used by the capitalists to justify their personal ego, greed and selfish acquisitiveness. ${ }^{16}$ Preston points out, 'Calvinism did crystallize its ethic round the new commercial society, and in a more confused way Catholic moral theologians were to follow' (Preston 1979:91). Tawney (cited in Preston 1979:95) rightly states that in an age of impersonal finance, world markets and capitalist organisations, the church tried to moralise economic relations by treating every transaction as a law of personal conduct. This is to say that in its individualism it failed to comprehend the new structures of economic life and the power relations that went with them. Traditional Christian thought on social issues became increasingly irrelevant, and in the end capitulated uncritically to the laissez faire view of the state and the economic order. The latter, however, was not intended. ${ }^{17}$ In his seminal work on The Social Teaching of the Christian Church, Ernst Troeltsch, the German sociologist of religion, thus rightly spoke of Calvin not as the source of modern capitalism, but rather as the source of Christian socialism in the modern world:

Here then - for the first time in the history of the Christian ethic - there came into existence a Christian Church whose social influence, as far as it was possible at the period, was comprehensive ... Calvinism was 'Christian Socialism' in the sense that it moulded in a corporate way the whole of life in the State and in Society, in the family, and in the economic sphere, in public and in private, in accordance with Christian standards. (Troeltsch 1956:622)

This view is supported by an examination of Calvin's interest in the welfare of the poor. Calvin's concern for the poor resulted in his attempt to transform his society, especially in Geneva. He concerned himself with the issues of commerce and economic justice. His theology was not disembodied, divorced from the realities of life where labourers and employers are often at odds over economic matters. Calvin realised that because of the nature of humanity and the sinfulness of our institutions, our endeavours are to some extent motivated by self-interest, pride, and greed. Yet his is a 'world-affirming theology' in the sense that he sought to apply the gospel to all of life. For him, that meant seeking the guidance of scripture for the problems besetting humanity, particularly those besetting the citizens of Geneva. Thus Calvin as a theologian and pastor became involved in everyday matters as diverse as the high cost of dying, 16.See, for example, the work of Max Weber (1930).

17.It is generally concluded that Calvin taught a biblical capitalism as distinguished from that theory of capitalism which is generally associated with Adam Smith and the laissez faire philosophy. Calvinism provides the only sure foundation for a biblical conception of the role and meaning of free enterprise. The secularised conceptions of the present day bear only a faint resemblance to the biblical conceptions of the present day bear only a faint resemblance to the biblical
economic theory of Calvinism with its emphasis on the human person's faithful economic theory of Calvinism with its emphasis on the
performance of stewardship over earthly possessions. 
hospitals, sumptuary laws, and the regulation of business and industry and the question of wages. Beyond the welfare system and education, the work of Calvin and the pastors extended to suggestions for railings to protect children on stairs and balconies. Fires and chimneys were regulated and efforts were made to clean the town and repair the streets. Regulation of prices for the necessities of life was an accepted principle of the early reformation in Geneva. Some people today may not agree with or approve of Calvin's stance, but they must concede that he regarded no area as too secular to be of legitimate Christian concern. ${ }^{18}$

Calvin's view as expressed above has implications for churches in South Africa. Churches need to recognise that their task is to take the whole Gospel to the whole person in the whole world. This implies that our care and responsibility for a person must not only attend to spirituality but to all aspects of a person's life: economic, social and political. The task is not just to change the individual but the environment in which that person lives. A stable society begins with each and every member of the society having the four basic rights: protection of life, protection of property and honour, freedom of speech as long as it does not endanger the first two protections, and access to health care and education. Imbalances in any of these are bound to destabilise society. The church therefore has the responsibility to attend to the needs of the whole person, bearing in mind the concept of ecodomy: fullness of life for all. Just as Calvin pointed out that the church cannot be detached from the realities of the people, so the church in South Africa must always seek the transformation of society to reflect the glory and justice of God.

South African society is characterised by poverty and inequalities. ${ }^{19}$ Inequalities in a society are a recipe for social instability and a denial of the fullness of life to human beings. We have not only seen this during apartheid in South Africa, but even see it now. The constant disruptions and violent protests in various municipalities indicate this rather strongly. The huge salary gap between management and workers creates a restless nation that is struggling to cope or to make ends meet financially. ${ }^{20}$ This has been rather conspicuous in the mining industry in South Africa. Unhappy and discontented people are not going to stay silent and oppressed forever. The church needs the wisdom to read these signs in advance and address them rather than merely being reactive when it happens. This context of inequalities and poverty presents a moral challenge for the church. This context of social instability offers a challenge to the church's mission and ministry. In Calvin's view the church has the responsibility to bring harmony and peace to

18.For more on Calvin's economic and social reforms see Andre Biéler (2005).

19.It is not within the scope of this article to go into the details of poverty and inequality in South Africa. For recent statistics on these see www.ngopulse.org/ article/inequality-south-africa.

20.For more information on this see The Measurement of Poverty in South Africa National Treasury, www.treasury.gov.za/publications/other/povertyline/SPII\%20 document.pdf. For more details on salary gaps see South Africa's massive wage document.pdf. For more details on salary gaps see South Africa's massive wage
gap - Business Tech, businesstech.co.za/news/general/59173/south-africasmassive-wage-gap and www.ngopulse.org/article/inequality-south-africa. society; therefore it needs to engage the causes of what brings disunity, faction and instability. What Calvin has taught us is that the reign and rule of God is not distanced from the everyday occurrences of life. So what can the church do to address these challenges?

Transformation requires that the church addresses the issue of inequalities. How do we use God-given resources to care, protect, enable and bless one another? Here the issues of inequalities, which bring social instability, must be addressed. How do we justify the fact that a few people control and manipulate the country's resources? How do we address this in the light of the Gospel? Here the church has a definite prophetic role to play as it confronts injustice, corruption and self- accumulation at the expense of others. The ability to maintain a stable society requires the presence of those who are able to constantly evaluate, assess, analyse and read the signs of our times. Calvin did this as he attempted to reform Geneva, believing it was his Christian responsibility to build the household of God (ecodomy). The church in South Africa needs the courage to call into question the decisions by political leaders when they implement systems that only favour a few. The church must serve as the moral conscience of society and ask the deeper justice questions and challenge structures that perpetuate inequalities in society if it is intentional about working towards the fullness of life for all. In South Africa, citizens see that the rich have more privileges. People also see what ends money can serve. For example, money and power can keep you out of jail or earn you a lesser sentence, even special privileges in jail. ${ }^{21}$ The wealthy continue to have privileges of power and protection, but what happens to the disadvantaged. Money gives you better access to medical care but hundreds of people die daily because they cannot access basic health care. ${ }^{22}$ Something is wrong with our society. Perhaps Jesus had the right words for this context: 'You cannot serve both God and Mammon. You will love the one and hate the other'. Transformation requires that we challenge and change oppressive and dehumanising structures and systems in society. As Calvin indicated, the wealth of the rich must be used to help those who are poor and destitute, and not merely be self-serving. This is necessary to create a stable and peaceful society. The church needs to assume more responsibility in this area and, perhaps, here we can learn from Calvin's initiatives.

To create a stable society and to work towards the fullness of life for all, the church needs to identify with the poor, as Calvin indicated. Why? The Bible speaks much about the poor: ani, rash, dal, potochos are biblical words that describe not only the spiritually poor but the one bent down, oppressed, disadvantaged, and economically and materially deprived people. ${ }^{23}$ These are the people who God identifies with as

21.The Oscar Pistorius case, for example, indicates this. If it was somebody else with lesser or no economic ability it would have been handled differently. The stories of the Waterfall Four, Commissioner Jackie Selibi and Schabir Shaik all tell us that the wealthy have more privileges in prison or receive parole sooner.

22.See inequities in access to healthcare in South Africa, www.palgrave-journals.com/ jphp/journal/v32/n1s/full/jphp201135a.html.

23. For more on this subject see my PhD dissertation, The Church and Development in the new South Africa: Towards a Theology of Development, UCT, 2002. 
God adopts their cause and defends their rights. The rich are, of course, also the people of God if they reach out and care for the poor as God requires. It is not wrong or sinful to be wealthy but it is important as to how a person acquired their wealth and what they do with it. Abraham was wealthy but he used his wealth to bless others.

In order to create a stable society the church must address the issue of poverty. ${ }^{24}$ The church needs to take time to fully understand the nature and causes of poverty. ${ }^{25}$ Some consider the causes of poverty primarily in the conditions and circumstances outside the poor themselves, such as racial or gender discrimination, poor schooling, and shifts in the job market. Others locate the primary cause of poverty in the attitudes and behaviours of the poor themselves, such as unrealistic expectations, non-completion of school, drug abuse, and failure to take responsibility for their own decisions. Whilst the personal element cannot be denied, research has shown that unequal and oppressive structural systems have resulted in many of the poor losing hope and their sense of value and self-esteem. ${ }^{26}$ In this context, what role can the church play?

The church needs to set up formal facilities to research, analyse and understand the causes and effects of poverty. It should use this facility to talk to government and impact on possible solutions in addressing poverty. As Calvin would say, the government ought to be the extension of the arm of God, therefore the church has the obligation to work with government in so far as it seeks to build community and strives towards the fullness of life for the poor and disadvantaged. The church has the unique opportunity to address both the personal and structural aspects of poverty. On the personal level, the church has a message to change people in positive ways. Research shows that people who are more religiously inclined and go to church regularly are more likely to seek better quality lives without drug and alcohol abuse and have stronger family lives and marriages. ${ }^{27}$ All of these can help to inspire and sustain values, hope and self-esteem, which can have an impact on addressing poverty.

On a structural level the church has existing infrastructure and can reach people on the ground far more effectively; this can be used to empower and develop a community. The church can embark on anti-poverty programmes. These programmes should seriously consider the following three principles or approaches to ascertain ecodomy. They should be people orientated, meaning that they should empower and develop the poor rather than make them dependent. The poor should be encouraged to participate in their own

24 .Statistics show that $26 \%$ of South Africans live on less than R305 a month. See the Poverty Profile of South Africa: Application of the poverty lines on the LCS 2008/2009, www.statssa.gov.za. More recent statistics indicate that more than 12 million people live in extreme poverty in South Africa. See www.dailymaverick. co.za/.../2015-02-03-south-africa.

25.For causes of poverty in South Africa, see povertyhci.weebly.com/causes-ofpoverty.html.

26.See author's PhD dissertation for more on this.

27. Refer to chapter 4 in my PhD dissertation for more information. processes of development which should be transformative in themselves. Here they must focus on the significance of human dignity. Anti-poverty programmes should have a strong preventative component, for example those finishing high school, and children born out of wedlock. An effective anti-poverty programme requires working with the poor on a personal, individual level to solve problems and supply the help needed, for example child care or transportation may be needed.

A point which needs to be reiterated here is that the church and religious bodies have a unique opportunity to address poverty. There are three reasons to support this claim. First, the church and religious bodies have greater flexibility. Government agencies are typically very large with bureaucratic structures and civil service employees are increasingly unionised. Thus, it is not easy to do new things, which sometimes has the potential to embarrass politicians. The church does not usually have the same drawbacks and is in a position to try new things more easily. There is also a sense of dedication and commitment to a cause which enables them to work long hours for less pay, or to volunteer. They usually approach their work as a mission as they serve both God and God's people and they have the ability to speak the language of morality and of religious or ethnic solidarity. They can impact on human behaviour and change it, something that no government agency can easily achieve. It is thus not surprising that the South African government is aware of this and constituted the Moral Regeneration Programme in which faith communities play a central role.

In addressing poverty the church needs to recognise that it needs to have partnerships with government, business and society. This calls for an integrated approach in addressing the needs of the poor, as Calvin would have said. However, churches should recognise their role and contributions in this and not allow themselves to compromise their own views, beliefs and practices. The goal of the church is not the same as politicians; rather it is a faithfulness and obedience to the call of Jesus who said, 'The Spirit of The Lord is upon me to proclaim goods news to the poor, to set the captives free ...' We need to understand and maintain this distinctiveness in our common endeavours to help the poor. As we have seen above, Calvin went to great lengths to indicate that the state and church both fall under the Lordship of Christ, but they each have distinct roles and responsibilities. We have seen in South Africa how the confusion of roles has, at times, led to the discrediting, compromising and complicity of the church. The church needs to maintain its prophetic witness and voice in the face of corruption and injustice in the land.

The Accra Confession adopted by the World Alliance of Reformed Churches in 2004 rejected unequivocally economic globalisation as dictated by the neo-liberal ideology. This Confession expresses what churches and Christians who emulate Jesus in their political and economic context should believe: God is a God of righteousness and liberation; God shows solidarity with the exploited and oppressed. The 
Accra Confession caused some confusion in Europe, which resulted in a joint project between the Reformed Church in Germany and the Uniting Reformed Church in southern Africa, which attempted to achieve a common theologically justified statement on neo-liberal globalisation. ${ }^{28}$ This 'Globalisation Project', as it was called, firmly stated that God's option for the poor is binding on the churches so that they too are placed by their Lord on the side of the poor and those deprived of their rights in order to be committed together to better justice. It made this statement in the belief that the earth was made by God and was entrusted to humanity, therefore we are called to be united in striving for the conservation of creation on the basis of (an ecological) justice (see Ahlerich Ostendorp 2010:134-135). The Project commenced with the question of human rights. It asserted that human dignity is an inalienable gift of God to every person, regardless of sex, ethnic origin, skin colour, ability, religious affiliation or political conviction. And from this God-given human dignity is then derived the validity of human rights for every person. The approach, which differs from Calvin's, shows that the poor are not the recipients of the compassionate contributions of the wealthy for which the poor should be thankful; the poor have a right to political and economic justice and a right to a decent life in which the right to sufficient healthy food, adequate accommodation, education and political participation becomes a reality. All these describe what is meant by ecodomy, fullness of life. Drawing from Calvin's understanding of ecodomy, it is indicated that in the South African context this means working towards the building of a just and peaceful human community connected with all human and non-human creation, understanding the relationship of state and church, transforming society to reflect the glory of God, engaging in the concerns of the poor and making a difference in the name of the Triune God.

\section{Education}

Calvin indicated that another way to build human community and address poverty and injustices is through spending time and resources on education. Education encourages the way towards the fullness of life and empowers people to participate in their own future and achievements. Thus, ideas on the education and schooling of European Reformed people were influenced as much by the humanists as they were by the Christian roots of Calvinist thought. Calvin broke with medieval pedagogy that limited education to the aristocratic elite. His Academy, founded in 1559, was a pilot programme in broad-based education for the city. He emphasised the importance of public education in the congregation and held parents accountable for the education of their children, as well as the entire community of believers. The public school, which had seven grades, enrolled 280 students during its inaugural year and the Academy's seminary expanded

28.The main debate evolved around the use of the words 'Empire, and "Confession" in the Accra Confession. Some churches and Christians in the countries of the north were confused, annoyed and unsettled by the Accra Confession. They sensed that their way of being a Church of Jesus Christ within the area of 'empire' was being questioned. However, representatives of the URCSA were adamant that there could be no joint document without reference to what was called 'Empire' in the 'Confession of Accra'. to 162 students in just three years. With Calvin's death in 1564 , there were 1200 students in the college and 300 in the seminary (Hall 2008:14). Both schools, as historians have observed, were tuition-free and 'forerunners of modern public education' (Kelly 1973:270). Another typical Reformed educational idea adopted by Calvin was that children should be schooled in the faith early on while they were still young and relatively free of sinful acts. However, it must be noted that the reformers sought to make public education available to all children, even where they were a religious minority. Understandably, in addition to the theology of Calvin, the educational practices and the organisation of schools in Geneva and other early Reformed areas were formative for the pedagogical ideas and educational policies of Reformed Europe.

Historically, education, as much as any other single factor, has fostered cultural and political advancement. The latter point can be seen in the South African context during the apartheid era when many political leaders went into exile in Europe, North America and other parts of the world, returning with degrees in various fields after being exposed to new realities and experiences that changed their lives. Education became the vehicle to unite, challenge and advance these people as they went to Christian mission schools and abroad to study. Education became the tool for liberation in South Africa in that educated people returning from exile or from exposure abroad were no longer content to remain unequal or oppressed. The importance of appropriate education cannotbeoverstated. It is a key to employment opportunities, population stabilisation, the exercise of human rights, effective public participation, disease prevention and health care, environmental conservation, economic productivity, agricultural sustainability, and cultural and spiritual development. Thus, it is indispensable for increasing both the quantity of goods and the quality of lives - the task of ecodomy.

The role of the church in South Africa and other faith communities in the area of education has had a major impact on the nation. It is thus not surprising that spirituality and religion still continues to undergird this country, even if at times we fail to admit to it. For example, the South African government was keen at one time to remove any religious attachments to education, but has since realised that this is not workable. Likewise, it has realised that the failure to recognise religious leaders is a recipe for disaster. The government needs the church and other faith communities to help create a stable society. This assertion is affirmed in the implementation of the National Development Plan where it is stated that if the Plan is to succeed there must be partnerships between the state, business and civil society and, in particular, faith-based organisations. The idea of fullness of life is embedded in Calvin's emphasis on education in working toward one developed humanity and a better society for all. Many churches have invested much in education in South Africa and should continue to do so in the quest to provide a better quality of life for all, especially the poor. 


\section{Conclusion}

The central theme of Calvin's theology is the conviction that every human being has to do with the living God every moment of every day. For the Reformed faith, God is involved in history, working out the divine plan of salvation. For Reformed Christians, involvement in the political and economic life of their country is clearly a matter of faith. It means that the importance of political, social and economic life is affirmed as the sphere of God's grace and involvement, and critiques the present state of political, social and economic life precisely because God's will of grace and salvation has not been fulfilled in any historical situation and in any given society or system. It is thus not surprising that, as this article has shown, the idea of ecodomy (working towards the fullness of life in Christ) pervades Calvin's thinking and theological teachings. It is also understandable why Calvin placed so much emphasis on unity and called for the church to live and work in unity in the world: everything in life is under the sovereign rule of God. As the church in South Africa continues its work in ecodomy it needs to embrace this theological foundation explicated by John Calvin which tells us that the sovereignty of God touches every area of life.

\section{Acknowledgements Competing interests}

The author declares that he has no financial or personal relationships which may have inappropriately influenced him in writing this article.

\section{References}

Bancroft, G., 1855, Literary and historical miscellanies, Harper \& Brothers, New York. Biéler, A., 2005, Calvin's economic and social thought, WARC \& WCC, Geneva.

Bouwsma, W., 1988, John Calvin: A sixteenth century portrait, Oxford University Press, New York.
Butin, P.W., 1995, Revelation, redemption and response: Calvin's Trinitarian understanding of the divine-human relationship, Oxford University Press, New York.

Buys, P.J., 2009, Calvinism and Racism: A South African Perspective, viewed n.d., from http://wrfnet.org/resources/2009/.../Calvinism-and-racism-south-africanperspective..

Gamble, R.C., 1992, Calvin's thought on economic and social issues and the relationship of church and state, Garland Publishing, New York.

Graham, F.W., 1971, The constructive revolutionary: John Calvin and his socioeconomic impact, John Knox, Richmond.

Hall, D., 2008, The legacy of John Calvin: His influence on the modern world, P\&R Pub. Co., Phillipsburg, New Jersey.

Hall, D., 2010, Tributes to John Calvin: A celebration of his quincentenary, P\&R Pub. Co., New Jersey.

Kok, J., 2014, 'The radicality of early Christian Oikodome: A theology that edifies insiders and outsiders', paper presented at a conference of the Faculty of Theology at the University of Pretoria, 27-28 October.

Kelly, D.R., 1973, Francois Hotman: A revolutionary's ordeal, Princeton University Press, Princeton.

Letham, R., 2004, The Holy Trinity in scripture, history, theology, and worship, P\&R Pub. Co., Phillipsburg, NJ.

McKim, D.K., 1984, Readings in Calvin's theology, Baker Book House, Michigan.

Mshana, R., 2012, Poverty, wealth and ecology in Africa: Ecumenical perspectives, WCC Publication, Geneva.

Ostendorp, A., 2010, 'The joint globalisation project - dialog on basic issues: Africa and the reformed church in Germany', in M. Wasserloos-Strunk (ed.), Europe covenanting for justice, pp. 134-135, Breklumer Print-Service, Germany.

Pavlovic, P., 2011, Poverty, wealth and ecology in Europe: Call for climate justice, CEC, Brussels.

Pillay, J., 2002, 'The church and development in the new South Africa: Towards a theology of development', PhD thesis, UCT.

Preston, R.H., 1979, Religion and the persistence of capitalism, SCM Press, London.

Schaff, P., 1979, History of the Christian church, Eerdmans, Grand Rapids.

Selderhuis, H.J., 2009, The Calvin handbook, Eerdmans, Michigan.

Torrance, T.F., 1956, Kingdom and church, Essential Books, Phillipsburg, New Jersey.

Troeltsch, E., 1956, The social teaching of the Christian churches, George Allen \& Unwin, London.

Van den Brink, G., 2010, The impact of Calvinism on the European mind - A plea for revisiting the issues, Calvin 500 Series, vol. 51., P\&R Pub.Co., Phillipsburg, New Jersey.

Weber, M., 1930, The Protestant ethic and the spirit of capitalism (1905), ET Allen \& Unwin and Scribner's, London.

Wendal, F., 1963, Calvin: Origins and development of his religious thought, transl. P. Mairer, Harper \& Row, New York.

Witte, J., 2007, The reformation of rights: Law, religion and human rights in early modern Calvinism, Cambridge University Press, Cambridge.

Witte, J., 2010, Christianity and human rights: An introduction, Cambridge University Press, Cambridge. http://dx.doi.org/10.1017/CBO9780511761713 